\title{
EXAMPLES OF SOLID WASTE ANALYSIS AND CHARACTERIZATION IN ACCORDANCE WITH CONTEMPORARY EUROPEAN ENVIRONMENTAL LEGISLATION
}

\author{
A. KARAGIANNIDIS ${ }^{1}$, M. CHRYSOCHOOU ${ }^{2}$, N. MOUSSIOPOULOS ${ }^{1}$, Z. SAMARAS $^{3}$ \& P. RAKIBEY ${ }^{1}$ \\ ${ }^{1}$ Laboratory of Heat Transfer and Environmental Engineering, Department of Mechanical Engineering, \\ Aristotle University of Thessaloniki, Thessaloniki, Greece. \\ ${ }^{2}$ Keck Geoenvironmental Laboratory, Center for Environmental Systems, Stevens Institute of Technology, \\ Castle Point on Hudson, Hoboken, U.S.A. \\ ${ }^{3}$ Laboratory of Applied Thermodynamics, Department of Mechanical Engineering, \\ Aristotle University of Thessaloniki, Thessaloniki, Greece.
}

\section{ABSTRACT}

European legislation specifies a series of analyses that have to be conducted in order to determine indicators on waste generation, treatment and disposal, as well as to ensure that the latter takes place in ways that ensure the protection of human health and environment. These analyses include sampling surveys in selected areas, determination of physicochemical and biological characteristics of waste, as well as the testing of material streams deriving from waste treatment and disposal. Waste characterization is not only directly imposed by European legislation, but is also indirectly required in order to plan and operate waste treatment facilities in a secure and cost-effective manner. This paper discusses the analyses imposed by legislation and the entire frame of analyses performed on waste, accompanied by examples and results that were derived in the frame of specific research projects, as well as their potential applications.

Keywords: European environmental legislation, physicochemical analyses, sampling surveys, waste characterization.

\section{INTRODUCTION}

European legislation on waste management was established for the first time in 1975 with the release of the Council Directive 75/442/EEC [1] on waste. According to the directive, each member state is obliged to draw up plans for rational waste management, relating to the type and quantities of disposed waste.

Waste management plans include, according to the Directive 91/156/EEC [2] that amended the Directive 75/442/EEC, the following components:

- type, quantity and origin of waste to be recovered or disposed,

- general technical requirements,

- special arrangements for particular waste,

- suitable disposal sites or installations.

The plans cover also the legal and financial aspects of the waste management chain.

The acquisition of data pertaining to the entire chain of waste production and disposal is hence directly imposed by the environmental laws, but is also indirectly required in order to facilitate planning of waste collection and transport, as well as construction and operation of waste management facilities. These data also provide general information on consumer behavior and preferences and trends in the use of materials and consumption of resources. The present paper discusses the types of data required by European environmental legislation, along with the analyses required for their acquisition, and presents examples of their application in different stages of the waste management chain. 


\section{EUROPEAN UP-TO-DATE LEGISLATION}

The European Council has released, since 1975, a number of directives, regulations and decisions on waste management, among which the following regulate waste analysis and characterization procedures:

- Council Directive 1999/31/EC [3] on the landfill of waste,

- Council Regulation (EC) No 2150/2002 [4] on waste statistics,

- Council Decision 2003/33/EC [5] complementing the Landfill Directive by establishing the criteria and procedures for the acceptance of waste at landfills.

The regulation on waste statistics concentrates on the quantities of different types of waste produced in particular activities. The member states are obliged to compile and deliver data concerning the quantities produced not only in households, but also in the specific industrial activities listed in Annex I of the regulation. Separate information is required on re-usable and disposable waste, as well as on the respective recycling and treatment facilities or sanitary landfills. Member states have to compile this data every second year beginning 2004 and deliver it to Eurostat within 18 months.

The Landfill Directive imposes waste characterization as a prerequisite for deposition in a particular type of landfill class (for inert, nonhazardous or hazardous waste). The Council Decision of December 19, 2002 defines the procedures for characterization and classification of waste that arrive in a sanitary landfill. These are based on a three-level hierarchy comprising the following steps:

1. Basic characterization: this is required for waste that is generated regularly by the same process and arrives for the first time in the landfill, as well as for waste not generated regularly. Information such as origin, composition, physical properties, leaching behavior and eventually the assigned landfill class is collected and recorded for each type of waste. The extent of laboratory testing is determined by the amount and precision of the data provided by the waste producer.

2. Compliance testing: regularly generated waste streams are tested periodically for compliance with the landfill class requirements at regular intervals after the basic characterization.

3. On-site verification: each load of waste has to be visually inspected before and after uploading. Member states can determine further tests that have to be carried out upon arrival at the landfill site.

Waste acceptance criteria include leaching limit values for several components, as well as other parameters (total content of organic substance groups, $\mathrm{pH}$, acid neutralization capacity, etc.) depending on the type of waste. Separate criteria are established for inert, nonhazardous and hazardous waste and the respective landfill classes. The Decision also defines the methods to be used for characterization; for example, the standard method EN 12457 will be employed as the default leaching test.

The Landfill Directive also specifies the control and monitoring procedures to be carried out in the operation and the aftercare phase of the landfill. These include:

- collection and supply of meteorological data (recommended in order to build water balances),

- sampling and analysis of leachate,

- sampling and analysis of surface waters as well as groundwater in the area,

- control of atmospheric emissions,

- control of the mechanical properties of the landfill body (settling behavior).

The Directive 2000/76/EC on incineration of waste imposes characterization only of hazardous waste arriving to incineration plants with the respective permit. The permit of operation includes, among others, a limit on the upper and lower heating values as well as the maximum content of pollutants of the hazardous waste treated. The Directive determines that samples from hazardous 
waste loads must be taken and analyzed periodically in order to ensure compliance with the limits set in the permit.

In addition to the legislative measures that impose waste analyses, the need for their application also arises from technical requirements for waste treatment and disposal plants. It is necessary, for example, to determine the physical properties of waste (heating value, moisture and ash content) in order to facilitate the operation of a waste incineration plant. Moreover, there are restrictions for the reutilization of certain kinds of waste, e.g. the chloride content of paper and the heavy metal content of incineration ash are decisive factors for their recycling and use in road construction, respectively.

\section{FIELD AND LAB-SCALE INVESTIGATIONS OVER THE WASTE LIFE CYCLE}

The first stage in the waste management chain that requires the collection of data is its generation. In order to determine the produced waste quantities and their composition in a selected area, the following methodology has prevailed, which pertains to municipal solid waste, since commercial and industrial waste is highly variable according to the activity and/or process generated [6].

1. Registration of truckloads in the recovery and disposal facilities: this step provides information on the total amount of waste that is produced, recycled and disposed. If special bins and trucks are used for the separate collection of materials (paper, plastic, glass, aluminum), the respective recovered quantities can be easily determined.

2. Sample collection: samples can either be collected from randomly selected bins or drawn from trucks upon arrival at the landfill site.

3. Sorting: samples are manually sorted into waste categories. Classification of the sample into different grain size classes is usually undertaken prior to the sorting procedure. Sorting can be implemented in two levels - first, sorting the sample into the main waste categories and second, sorting each category into more specific subcategories (see Table 1).

Koufodimos and Samaras [7] present an example of a sampling survey conducted in the municipality of Pilea, in Thessaloniki, Greece. The sorting method applied was direct collection from premarked bins of known capacity, which varied from $240 \mathrm{~L}$ to $1100 \mathrm{~L}$. The load was collected by waste collection vehicles and the final sample, on which sorting was applied, was taken from the total collected waste load via the quartering technique. The volume of the total collected load was $30 \mathrm{~m}^{3}$, while that of the final sample was $3 \mathrm{~m}^{3}$. Figure 1 presents the results of the survey along with the seasonal variation in the waste composition.

The organics fraction presented a maximum yield in summer, when consumption of fruits and vegetables is significantly higher in Mediterranean countries, along with an increase in the garden and park waste. Paper consumption also presents high deviations in the four seasons, while other fractions present a rather uniform contribution in all the seasons. The fraction of 'miscellaneous' waste is an exception and yields a significantly higher percentage in the winter.

The data collected from sampling surveys can be exploited in diverse applications:

- determining the recycling and material recovery potential,

- designing and constructing waste management facilities (material recovery facilities, composting, anaerobic digestion and/or incineration plants and landfill sites),

- sizing and locating waste collection bins for residual waste as well as for recyclables,

- formulating and calculating indicators related to waste, e.g. temporal evolution of waste generation, waste generation per capita, waste and economic activity, etc. [8]. 
Table 1: Waste categories for sorting procedures [7].

\begin{tabular}{|c|c|c|}
\hline Main category & Subcategory 1 & Detailed subcategory 2 \\
\hline Organics & Organic waste & $\begin{array}{l}\text { Food waste } \\
\text { Yard waste }\end{array}$ \\
\hline Paper & $\begin{array}{l}\text { Paper } \\
\text { Paperboard }\end{array}$ & $\begin{array}{l}\text { Packaging } \\
\text { Magazines, newspapers, office papers } \\
\text { Others } \\
\text { Packaging } \\
\text { Others }\end{array}$ \\
\hline Plastics & Plastics & $\begin{array}{l}\text { Polyolefins } \\
\text { Bottles, vases (PVC, PET and PEHD) } \\
\text { Others }\end{array}$ \\
\hline Metals & Metals & $\begin{array}{l}\text { Metal items } \\
\text { Aluminum } \\
\text { Others }\end{array}$ \\
\hline Glass & Glass & $\begin{array}{l}\text { Packaging } \\
\text { Others }\end{array}$ \\
\hline LWTR & $\begin{array}{l}\text { Textiles } \\
\text { Nonclassified, combustible }\end{array}$ & $\begin{array}{l}\text { Textiles } \\
\text { Wood } \\
\text { Others }\end{array}$ \\
\hline Noncombustible & $\begin{array}{l}\text { Nonclassified } \\
\text { Special waste }\end{array}$ & $\begin{array}{l}\text { Nonclassified, noncombustible } \\
\text { Batteries, accumulators } \\
\text { Others }\end{array}$ \\
\hline Others (miscellaneous) & $\begin{array}{l}\text { Sanitary waste } \\
\text { Synthetics } \\
\text { Miscellaneous }\end{array}$ & $\begin{array}{l}\text { Sanitary waste } \\
\text { Packaging } \\
\text { Others } \\
\text { Miscellaneous }\end{array}$ \\
\hline
\end{tabular}

LWTR: leather, wood, textiles and rubber.

It is of key importance to all aforementioned procedures that surveys and analyses are conducted by implementing standard methods available in order to ensure continuity and comparability of the results. Parameters often mentioned as affecting the production and composition of municipal waste are: social factors such as age, sex, income, educational level, size and status of family; residential structure patterns; waste management and organizational patterns such as bin size, collection system; waste fees; and seasonal variation. These factors are used as stratification criteria in order to employ a stratified random sample and to reduce the sample size. A project funded by the Fifth Framework Program aims at developing a standardized methodology for solid waste analysis of household-type waste with the objective of improving the quality and comparability of waste sampling surveys [9]. Statistical analysis conducted on existing data sets so far has indicated that residential structure, bin size and source of waste (household and commercial) are the most significant stratification criteria [10]. 


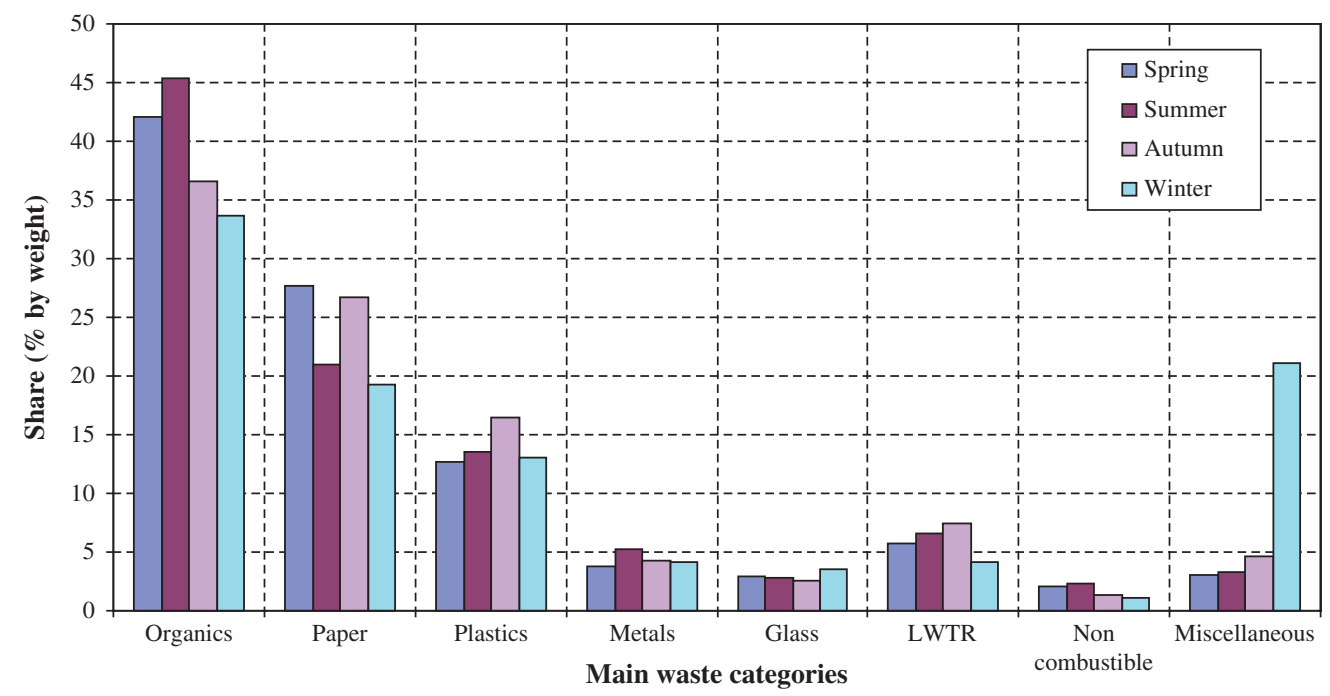

Figure 1: Example of sampling survey results [7].

Samples collected from sampling surveys can then be submitted to a series of analyses in order to determine their physicochemical characteristics. Table 2 provides an overview of parameters, the measurement principle or the respective apparatus used and their potential applications.

In the aforementioned sampling survey in Pilea, samples of $2 \mathrm{~kg}$ each were drawn from the organics, paper, plastic and LWTR fractions and analyzed with the following steps:

- Drying in a furnace at $150^{\circ} \mathrm{C}$.

- Determination of weight loss every $24 \mathrm{~h}$ and of moisture content.

- Grinding in fractions of $2 \mathrm{~mm}$ and $4 \mathrm{~mm}$ diameter.

- Determination of the heat value in a bombshell calorimeter.

- Incineration at $480-950^{\circ} \mathrm{C}$ and determination of the ash content. Table 3 presents the analysis results of the described steps for the individual fractions.

- Chemical analysis in the organics ash, in order to determine the concentration in heavy metals, toxic elements, polychlorinated dioxins and furans, as well as toxicity and alkalinity. Results from the heavy metal analyses are presented in Table 4 .

The results of the ash and moisture content of the combustible fraction are illustrated in a Tanner diagram (Fig. 2). The area under the bold line marks the materials that can be combusted without the use of additive fuel. The waste of Pilea lie within that area and therefore qualify for incineration.

Heavy metal concentrations in the organics fraction are important in order to evaluate the quality of compost in the case that a composting or a mechanical-biological treatment facility is under consideration in the sample area. The concentrations measured in the ash in the presented example are, however, not total concentrations of the organics fraction, since a percentage is carried away with the exhaust gas during the incineration. This percentage varies among the heavy metals, e.g. $94 \%$ of lead remains in the ash, while $95 \%$ of mercury and $93 \%$ of cadmium are carried away with the exhaust gases [11].

Heavy metal concentration in waste incineration ash plays a significant role in its reuse in road construction. The German Joint Länder Working Group on Waste has, for example, released a 
Table 2: Experimental methods to determine the main physicochemical and biological properties of waste.

\begin{tabular}{|c|c|c|c|}
\hline Parameters & Unit & Determination principle/device & Application \\
\hline \multicolumn{4}{|l|}{ Physical } \\
\hline $\begin{array}{l}\text { Particle size } \\
\text { and size } \\
\text { distribution }\end{array}$ & $\mathrm{mm}$ & $\begin{array}{l}\text { Passing through filter(s) of } \\
\text { the desired diameters }\end{array}$ & $\begin{array}{l}\text { Assessment of sorption } \\
\text { properties, mobility of } \\
\text { chemical compounds }\end{array}$ \\
\hline Density & $\mathrm{kg} / \mathrm{m}^{3}$ & $\begin{array}{l}\text { Weighing of waste contained } \\
\text { in a specific volume }\end{array}$ & $\begin{array}{l}\text { Calculation of required } \\
\text { storage and/or landfill space }\end{array}$ \\
\hline $\begin{array}{l}\text { Moisture } \\
\text { content }\end{array}$ & $\%$ & $\begin{array}{l}\text { Weighing and drying until the } \\
\text { weight stabilizes, the difference } \\
\text { corresponds to the moisture } \\
\text { content }\end{array}$ & $\begin{array}{l}\text { Depends on the type of } \\
\text { treatment or disposal } \\
\text { (composting, incineration or } \\
\text { landfilling) }\end{array}$ \\
\hline Heating value & $\mathrm{kJ} / \mathrm{kg}$ & Bomb calorimeter & Incineration calculations \\
\hline \multicolumn{4}{|l|}{ Chemical } \\
\hline $\begin{array}{l}\text { Composition } \\
(\mathrm{C}, \mathrm{H}, \mathrm{O}, \mathrm{N}, \mathrm{S})\end{array}$ & $\%$ & Elemental analyzer & $\begin{array}{l}\text { Depends on the type of } \\
\text { treatment or disposal } \\
\text { (composting, incineration or } \\
\text { landfilling) }\end{array}$ \\
\hline Ash content & $\%$ & $\begin{array}{l}\text { Weighing the residue after } \\
\text { combustion in an open } \\
\text { crucible [6] }\end{array}$ & Incineration calculations \\
\hline $\begin{array}{l}\text { Volatile } \\
\text { combustible } \\
\text { matter }\end{array}$ & $\%$ & $\begin{array}{l}\text { Determination of additional loss } \\
\text { of weight on ignition at } 950^{\circ} \mathrm{C} \\
\text { in a covered crucible [6] }\end{array}$ & Incineration calculations \\
\hline Fixed carbon & $\%$ & $\begin{array}{l}\text { Determination of combustible } \\
\text { residue after volatile matter is } \\
\text { removed [6] }\end{array}$ & Incineration calculations \\
\hline $\begin{array}{l}\text { Carbon } \\
\text { speciation } \\
\text { (total organic } \\
\text { carbon (TOC)) }\end{array}$ & $\%$ & TOC analyzer & $\begin{array}{l}\text { Depends on the type of } \\
\text { treatment or disposal } \\
\text { (composting, incineration or } \\
\text { landfilling) }\end{array}$ \\
\hline $\begin{array}{l}\text { (Heavy) metal } \\
\text { content }\end{array}$ & $\begin{array}{c}\text { Dry } \\
\text { substance } \\
\text { (DS) } \\
\mathrm{mg} / \mathrm{kg}\end{array}$ & $\begin{array}{l}\text { Digestion (acid and/or } \\
\text { microwave-assisted) and } \\
\text { subsequent atom absorption } \\
\text { spectroscopy }\end{array}$ & $\begin{array}{l}\text { Assessment of heavy metal } \\
\text { mobility in compost, ash or } \\
\text { waste deposited in a soil or } \\
\text { landfill }\end{array}$ \\
\hline \multicolumn{4}{|l|}{ Biological } \\
\hline $\begin{array}{l}\text { Respiration } \\
\text { activity }\end{array}$ & $\mathrm{DS} \mathrm{g} / \mathrm{kg}$ & $\begin{array}{l}\text { Sapromat, Respiromat - } \\
\text { determination of pressure loss } \\
\text { due to oxygen consumption }\end{array}$ & $\begin{array}{l}\text { Mainly for assessment of } \\
\text { biological treatment }\end{array}$ \\
\hline $\begin{array}{l}\text { Gas building } \\
\text { rate }\end{array}$ & DS L/kg & $\begin{array}{l}\text { German Standard Method } \\
\text { DIN } 38414 \text { Part } 8\end{array}$ & $\begin{array}{l}\text { Mainly for assessment of } \\
\text { biological treatment }\end{array}$ \\
\hline
\end{tabular}


Table 4: Concentrations of heavy metals $(\mathrm{mg} / \mathrm{kg})$ in the ash of the organics fraction [13].

\begin{tabular}{|c|c|c|c|c|c|c|c|}
\hline Sample date & As & $\mathrm{Cd}$ & $\mathrm{Cr}$ & $\mathrm{Cu}$ & $\mathrm{Pb}$ & Mn & $\mathrm{Zn}$ \\
\hline \multicolumn{8}{|c|}{ First sample - spring } \\
\hline 02.04 .98 & 1.3 & 0.5 & 64 & 27 & 28 & 74 & 197 \\
\hline 03.04 .98 & 2.2 & 0.7 & 62 & 32 & 12 & 88 & 210 \\
\hline 08.04 .98 & 9.3 & 1.0 & 33 & 26 & 19 & 134 & 217 \\
\hline 09.04 .98 & 0.4 & 0.4 & 79 & 33 & 10 & 34 & 94 \\
\hline 10.04 .98 & 1.5 & 0.5 & 72 & 33 & 12 & 46 & 158 \\
\hline \multicolumn{8}{|c|}{ Second sample - summer } \\
\hline 23.07 .98 & 8.6 & 0.5 & 231 & 42 & 16 & 253 & 253 \\
\hline 24.07 .98 & 4.2 & 0.7 & 320 & 59 & 15 & 317 & 1240 \\
\hline 29.07.98 & 2.3 & 0.6 & 103 & 55 & 26 & 183 & 270 \\
\hline 30.07 .98 & 3.9 & 1.0 & 419 & 7622 & 61 & 284 & 927 \\
\hline 07.08 .98 & 8.3 & 0.4 & 87 & 49 & 45 & 179 & 2167 \\
\hline \multicolumn{8}{|c|}{ Third sample - autumn } \\
\hline 21.10 .98 & 2.1 & 1.0 & 97 & 30 & 40 & 100 & 350 \\
\hline 22.10 .98 & 2.2 & 1.1 & 67 & 3060 & 121 & 150 & 390 \\
\hline 29.10 .98 & 17.4 & 1.1 & 25 & 20 & 2 & 50 & 130 \\
\hline 30.10 .98 & 1.3 & 0.7 & 26 & 20 & 30 & 80 & 110 \\
\hline 03.11 .98 & 0.4 & 0.9 & 32 & 30 & 4 & 70 & 190 \\
\hline \multicolumn{8}{|c|}{ Fourth sample - winter } \\
\hline 10.12 .98 & 2.1 & 0.6 & 59 & 430 & 49 & 130 & 850 \\
\hline 15.12 .98 & 7.6 & 0.9 & 45 & 30 & 23 & 220 & 220 \\
\hline 15.12 .98 & 1.1 & 0.7 & 27 & 30 & 6 & 180 & 180 \\
\hline 15.12 .98 & 0.9 & 0.7 & 27 & 20 & 4 & 160 & 160 \\
\hline 15.12 .98 & 1.0 & 1.0 & 117 & 90 & 11 & 250 & 250 \\
\hline $15.12 .98^{*}$ & 2.8 & 1.1 & 61 & 430 & 54 & 960 & 960 \\
\hline $15.12 .98^{*}$ & 2.3 & 1.1 & 5.2 & 60 & 16 & 340 & 340 \\
\hline Average & 2.8 & 0.8 & 96 & 556 & 27 & 141 & 448 \\
\hline
\end{tabular}

${ }^{*}$ Samples from ash of garden waste.

document providing guidelines and heavy metal concentration limits for reuse of incineration ash in road construction [12].

Apart from the determination of the general characteristics and total concentrations of chemical compounds in solid waste, the Landfill Directive requires (in certain cases, as described in the previous section), the assessment of the waste leaching behavior. Leaching tests are used in order to estimate the mobilization potential of substances from the solid into the liquid phase. Diverse forms of leaching tests have been developed in the last 20 years, varying in the amount of solid and liquid used, the agitation form, the duration, chemical additives used, etc. Results from different leaching tests were therefore difficult or even impossible to compare. The European Committee for Standardisation (CEN) resolved this issue at the European level by developing and providing a set of standard leaching methods to be used for waste characterization, as determined in the Council Decision of December 19, 2002 (2003/33/EC) [5]. 


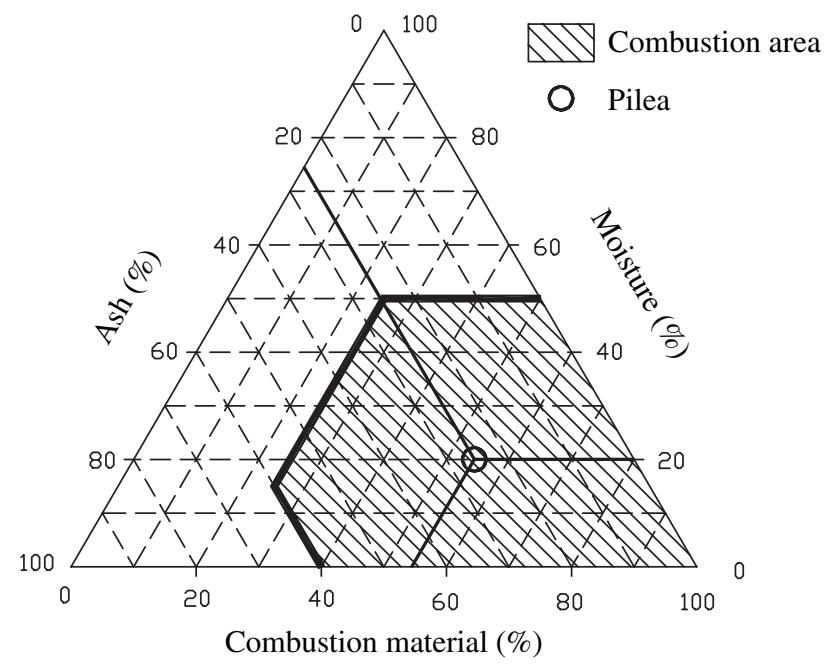

Figure 2: Tanner diagram for the combustible fractions of the sample collected in Pilea [7].

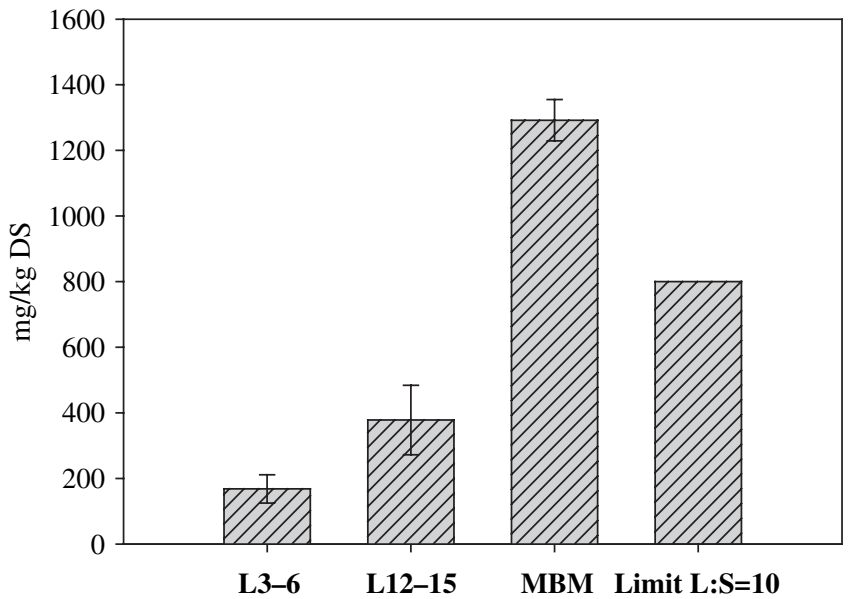

Figure 3: Dissolved organic carbon (DOC) in leachate from three waste samples compared to the European limit value for a liquid-solid ratio (L:S) of 10 [14].

Figure 3 presents an example of the results of leaching tests performed on mechanically-biologically treated and landfilled waste in the frame of the research project 'Sickerwasserprognose' (Leachate Prognosis) in the Dresden University of Technology [14]. Two materials were drawn from a landfill operated between 1977 and 1998 in Saxony, Germany, from two different depths (L3-6 was drawn from a depth of 3-6 m and L12-15 from the landfill bottom at a depth of 12-15 m), thus representing waste of different deposition ages. The mechanically-biologically treated material came from a mechanical-biological treatment facility for mixed household waste, located in Saxony, Germany. The test used was a method proposed by the German Institute for Standardisation DIN 48414 Part 4. The test was used as the basis for the development of the CEN method EN 12457 part 1 (DEV S4), 
so that the results can be compared for the respective limit values for nonhazardous waste provided by the Decision 2003/33/EC [5].

The experiment showed that waste deposited for a long time (10-15 years respectively for the materials L3-6 and L12-15) do not pose a threat if the deposition place fulfills the safety requirements of a sanitary landfill. Low-molecular, soluble organic compounds are either biodegraded or bound into high-molecular, insoluble humic substances over the years, so that the released dissolved organic carbon (DOC) concentrations lie beneath the European limit value. The older material presents higher concentrations, because organic matter washes out and moves to deeper ground levels.

Heavy metal concentrations obtained from leaching tests are also used, together with total concentrations, in order to evaluate whether materials such as municipal waste incineration ash (MWIA) are suitable for reuse. Figure 4 presents a comparison between concentrations measured using DEV S4 with limit values given in the respective aforementioned document [12]. The MWIA was provided by the German Federal Institute for Material Research and Testing as reference material in the frame of the aforementioned project 'Leachate Prognosis'. The comparison reveals that the MWIA is suitable for reuse, although concentrations of some substances (nickel and copper) are relatively high. This procedure is particularly important, since unfavorable conditions, like low $\mathrm{pH}$ values as a result of acid rain, can lead to heavy metal mobilization [15] and pose a threat to soil and underground water.

A measure for the probability that a deposited material presents low $\mathrm{pH}$ values due to penetration of acid rain and to acid formation through bacterial activity is given by its acid neutralizing capacity (ANC). The ANC corresponds to all bases contained in a material that are neutralized by adding a strong acid, such as $\mathrm{HCl}$, in a process called 'titration' and is determined by the amount of acid added to $1 \mathrm{~kg}$ of material at a constant $\mathrm{pH}$ value (usually 7 or 7.5 ) for a limited period of time (usually $24 \mathrm{~h}$ ). Kouras, Voutsa and Kouimtzis [16] measured the ANC of bottom ash produced by the incineration of municipal waste collected in the aforementioned sampling survey in Pilea. The ANC at $\mathrm{pH} 7.5$ was $2.0-2.5$ meq, a relatively high value, so that the ash can act as a natural buffer. Until this buffer

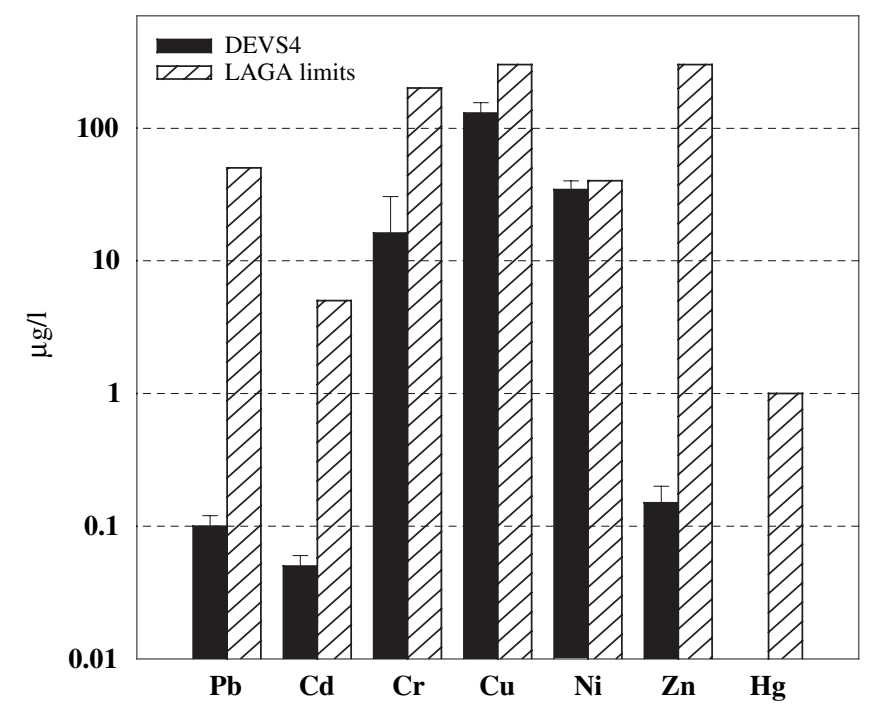

Figure 4: Heavy metal concentrations in leachate obtained from municipal waste incineration ash, compared to limit values provided by the German Joint Länder Working Group on Waste [14]. 
capacity is reached, the $\mathrm{pH}$ values will remain in the neutral area and the mobility of many heavy metals will remain low [16].

Leachate analysis is also of vital importance in a sanitary landfill. The effectiveness of leachate treatment has to be verified periodically by testing the quality of the input and output. At the landfill of Ano Liossia, a major landfill site in the Athens greater area, the quality of leachate was studied in various depths down to the bottom of the landfill by means of exploratory drills. The leachate's quality exhibited great variations depending on the stage of solid waste decomposition [17]. The results of various tests conducted on the leachate pointed at the appropriate treatment to produce an acceptable effluent: (1) chemical oxidation to break down stable organics, (2) aerobic treatment to reduce ammonia concentrations [18].

\section{CONCLUSIONS}

Waste characterization is an integral part of waste management in all its stages. It is not only directly imposed by European legislation, but is also necessary in order to obtain information on the quantity and quality of all types of waste and plan its collection, transport, storage, treatment and final disposal in the most effective manner. It is also a means of assessing the threat that might be posed to human health and environment and to ensure that environmental protection takes place according to the standards set by national and European laws.

More specifically, the following procedures and results are envisaged: data on waste quantities produced in a designated area, as well as data on its composition provided by sampling surveys contribute to drawing up waste management plan and planning waste treatment and disposal facilities. In case no previous data exist, a detailed description of the properties of waste, concerning the determination of physicochemical and biological characteristics is required. Analyses in waste treatment plants extend to other streams deriving from their operation, such as analysis of leachates produced in a sanitary landfill or of exhaust gases from an incineration plant.

Specific examples include determination of energy, ash and moisture content in case an incineration facility is considered, or determination of the organic fraction, its heavy metal content and the biological activity, in case a composting facility is planned. If waste treatment and disposal facilities already exist, properties of both incoming waste and produced residues have to be periodically determined in order to ensure the smooth function of the facility. Thus, there is a clear necessity of an integrated approach over the entire life cycle of waste.

\section{REFERENCES}

[1] Directive of the European Council of 15 July 1975 on waste (75/442/EEC), Official Journal of the European Communities, No. L 194, p. 39, 1975.

[2] Directive of the European Council of 18 March 1991 amending Directive 75/442/EEC on waste (91/156/EEC), Official Journal of the European Communities, No. L 078, pp. 32-37, 1991.

[3] Directive of the European Council of 26 April 1999 on the landfill of waste (99/31/EC), Official Journal of the European Communities, No. L 082, pp. 1-19, 1999.

[4] Directive of the European Council of 25 November 2002 on waste statistics, Official Journal of the European Communities, No. L 332, pp. 91-111, 2002.

[5] Decision of the European Council of 19 December 2002 (2003/33/EC), establishing criteria and procedures for the acceptance of waste at landfills, pursuant to Article 16 of and Annex II to Directive 99/31/EC, Official Journal of the European Communities, No. L 11, pp. 27-49, 2002.

[6] Tchobanoglous, G., Theisen, H. \& Vigil, S.A., Integrated Solid Waste Management: Engineering Principles and Management Issues, McGraw-Hill, 1993. 
[7] Koufodimos, G. \& Samaras Z., Waste management options in southern Europe using field and experimental data. Waste Management, 22(1), pp. 47-59, 2002.

[8] European Environmental Agency, Environmental Signals, Environmental assessment report No. 6, 2000, http://reports.eea.eu.int/signals-2000/en

[9] Development of a methodological tool to enhance the precision and the comparability of solid waste analysis data, project funded under the Energy, Environment and Sustainable Development (EESD) specific programme of the 5th Framework Programme of the European Commission, key action 'The City of Tomorrow and Cultural Heritage', http://www.swa-tool.net, 2001-2004.

[10] Ploechl, C., Dobson, G. \& Buell, U., Factors influencing municipal waste arising and composition. 8th Conference on Environmental Science and Technology, Lemnos, Greece, 2003.

[11] Huber, H., Jaros, M. \& Lechner, P., Emission Behaviour of Municipal Waste Incineration Ash after Artificial Aging, Final Report, Institute for Applied Geology, Vienna, 1996.

[12] LAGA (German Joint Länder Working Group on Waste), Guidance document on the disposal of ashes deriving form household waste incineration, GABI No. 1, p. 66, 1995.

[13] Moussiopoulos, N., Samaras, Z., Kouimtzis, Th., Karagiannidis, A., Voutsa, D., Perkoulidis G., Koufodimos, G. \& Kouras, A., Sampling, field work and laboratory analyses in the frame of integrated investigation of municipal solid waste management in Thessaloniki, Greece. Proceedings of the 1st Environmental Conference of Macedonia, Thessaloniki, Greece, 1-4 March 2002.

[14] Chrysochoou, M., Comparison of leaching tests for the characterisation of substance release from deposited waste, Master's thesis, Institute for Waste Management and Contaminated Site Treatment, Dresden University of Technology, 2003.

[15] Worch, E., Water and Water Substances: An Introduction to Hydrochemistry, Series Environment, Teubner: Stuttgart, 1997.

[16] Kouras, A., Voutsa, D. \& Kouimtzis, Th., Characterization of bottom ash produced from combustion of fermentable matter of municipal solid wastes from northern Greece. Fresenius Environmental Bulletin, 10(8), pp. 669-673, 2001.

[17] Kouzeli-Katsiri, A., Christoulas, D., Bosdogianni, A. \& Koumoulos, D., Leachate production and transformations in sanitary landfills. Proceedings of HELECO 1992, Vol. 1, pp. 149-161, 1993.

[18] Karagiannidis, A., Selecting and applying a multicriteria decision aid method for the management of municipal solid waste in a south-east European region, Master's thesis, National and Kapodistrian University of Athens, 1994. 